\title{
A benefits framework for public access ICT4D programmes
}

\section{Corrie Uys ${ }^{1}$ ( ) I Shaun Pather ${ }^{2}$}

${ }^{1}$ Centre for Postgraduate Studies, Cape Peninsula University of Technology, Cape Town, South Africa

${ }^{2}$ Information Systems, University of the Western Cape, Cape Town, South Africa

\section{Correspondence}

Corrie Uys, Centre for Postgraduate Studies, Cape Peninsula University of Technology,

Cape Town, South Africa.

Email: uysc@cput.ac.za

Funding information

South African NRFGMSA, Grant/Award

Number: SGD14051267186.

\begin{abstract}
There have been expectations across the developing world that information and communications technologies (ICTs) will deliver benefits to marginalised people. Despite many programmes related to the promotion of Internet uptake and usage amongst poorer communities, evidence regarding such benefit is lacking, and there is little agreement in respect of frameworks and metrics to evaluate the benefits thereof. This paper reports on a case study that investigated the nature of a public access information and communication technologies for development (ICT4D) programme and presents a framework for assessing the associated benefits in the South African context. The capability approach is used as a lens to assess the process of providing opportunities to ordinary citizens through ICT access and use. By operationalising agency and conversion factors, the study identified inhibitors and enhancers of opportunities and choices in realising benefits. Through the application of a critical realism paradigm and a mixed method analytical approach, perceptions of a changed life, aspirations for a better life, and "hope" emerged as key intangible benefits. The paper presents an ICT benefits framework, which serves as an important contribution to the ICT4D evaluation field. A novel outcome of the study is that it provides evidence of constructs that to date have been considered as intangible benefits in the literature.
\end{abstract}

\section{KEYWORDS}

capability approach, development, evaluation, ICT4D, information and communications technologies, public access centres

\section{1 | INTRODUCTION}

Information and communications technology (ICT) has been punted as a necessary factor in the quest for development. In the words of Sam Pitroda,

[As] a great social leveller, information technology ranks second only to death. It can raze cultural barriers, overwhelm economic inequalities, even compensate for intellectual disparities. In short, high technology can put unequal human beings on an equal footing, and that makes it the most potent democratizing tool ever devised. (Pitroda, 1993)

While massive strides have been made to harness the benefits of the Internet for commerce and industry, large sectors of society, especially in the least developed countries (LDCs), are either still unaware of the benefits of modern ICTs or do not have access to ICTs, especially broadband Internet. This is of concern especially since the Millennium Development Goals (MDGs) process (UNESCO, 2002) showed that ICTs is essential to sustainable development, enabling and enhancing their users' capabilities (ITU, 2014, p. 402). 
The "Final WSIS Targets Review" of 2014 reported that ICT access and use is still not equally distributed, even though growth in ICT networks, services and applications, and content has moved the global information society forward since the 2003 and 2005 World Summit on the Information Society (WSIS) (ITU, 2014, p. 388). By 2014, only 40.6\% of the world's population were Internet users (ITU, 2015). However, only $15 \%$ of households in LDCs have Internet access at home, and as such, many Internet users are accessing the Internet from work, schools and universities, or from other shared public connections outside the home (ITU, 2017).

The Internet penetration levels in South Africa are also at unacceptably low levels. Only $64.7 \%$ of South African households had at least one member who had access to or used the Internet either at home, work, place of study, or Internet cafés, and $60.1 \%$ of households has access to the Internet via mobile devices (Statistics South Africa, 2019). Only 10.4\% of South African households had access to the Internet at home. Given the low access levels at household level, which is more pronounced amongst lower income earners, the need for programmes to provide subsidised Internet access at a community level has become paramount. This is especially important given the high costs of data on mobile networks.

The South African government launched various programmes in an effort to meet the country's commitments to information society-related targets. Examples of these include community telecentres, multipurpose community centres or Thusong centres* (DOC, 2013), school cyberlabs (eg, Khanya Education Technology Project ${ }^{\dagger}$ ), Dinaledi Schools (DBE, 2014), Cape Access (Western Cape Government, n.d.), SmartCape Access project (Smart Cape, 2010), and similar projects at national, provincial, and local government level (Pather, 2012). These interventions at centres where the public can have free access to the Internet are typically reported as public access information and communication technologies for development (ICT4D) programmes.

The evaluation of such developmental projects is necessary to determine whether the goals of developing and benefitting communities socioeconomically have been achieved. This is important, given the reports of failures of ICT4D projects (Heeks, 2005). In South Africa, Van Rensburg, Veldsman, and Jenkins (2008, p. 77) point out that "the relatively simplistic views of the 'enabling powers' of ICT in the development arena have failed to deliver on the promised development goals, whether Millennium Development Goals (MDG) or otherwise." In particular, Goal 8 of the MDG set by UNESCO listed the target of "making benefits of new technologies, especially ICTs, available to all" (Andries, 2009, p. 1). The MDGs were followed on by the 17 Sustainable Development Goals (SDGs). Goal 17 specifically targets access to technology. This need for monitoring and evaluating of projects continues to be important in lieu of the post-2015 UN development agenda (United Nations, 2015).

Although frameworks for evaluation exist, there are no prescribed methods or established guidelines within the areas of ICT4D or community informatics as to which framework to utilise in undertaking evaluation exercises (O'Neil, 2002, p. 77). The Director of the Massachusetts Institute of Technology (MIT) India lamented in 2002 that almost nothing is known of factors for the effectiveness or ineffectiveness of ICT projects in developing nations (Keniston, 2002). By 2005, Rothenberg-Aalami and Pal (2005) and Colle (2005, p. 6) confirmed that there is only scant and anecdotal evidence that community-based ICT projects are benefitting communities. Other studies, such as Grunfeld (2007, p. 7; 2011, pp. 3233), reported that gaps in the knowledge of benefits or impacts of ICT initiatives exist. Others have also been critical of the existing ICT4D evaluation paradigms that focussed mainly on evaluating measureable and quantifiable outcomes (Gomez \& Pather, 2012). This study aimed to widen the scope to include nonmeasurable outcomes, which can be classified as intangible benefits.

The underlying rationale of this study was informed by the problem that governments, non-governmental organisations (NGOs), and other agencies in the ICT4D arena do not (as yet) have frameworks to establish if ICT4D investments are yielding benefits in communities. The objectives of the research reported in this paper were to identify the nature of the benefits in a selected ICT4D initiative and to develop a framework for benefits of ICT4D initiatives. In pursuance of the latter objectives, the principal research question of this study was the following: What are the benefits of public access ICT4D programmes deployed in local communities?

\section{2 | LITERATURE REVIEW}

\section{1 | Public access ICT4D programmes: South African context}

During the reign of the South African apartheid government (up to 1994), services and goods were distributed extremely unevenly, which resulted in the democratically elected, post-apartheid government inheriting an inequitable society of various developmental levels with a huge gap between the rich and the poor (Langa, Conradie, and Roberts (2006). Consequently, from 1994, the government focused its policies and programmes on the eradication of historical societal injustices (Gomez, Pather, \& Dosono, 2012) and as such has prioritised economic development policies, amongst which one of its main objectives is the improvement of the telecommunications infrastructure to further developmental goals (South Africa, DTPS, 2016).

Both policy and interventions of the South African Government demonstrate that it views opportunities presented by the use of ICT as one of the means by which economic growth can be sustained. Progress made in addressing the digital divide in South Africa over the past two decades include several actions ranging from policy frameworks, legislation, and the establishment of organisational capability such as that of the

*The Thusong Service Centre (formerly Multi-Purpose Community Centre/MPCC) programme of government was initiated in 1999 with the aim of implementing development communication and information to rural communities.

The Khanya project was launched in 2002 and was active until 2012 
Universal Service and Access Agency. More recently, the National Integrated ICT Policy White Paper was gazetted, which presents an "overarching policy framework for the transformation of South Africa into an inclusive and innovative digital and knowledge society" (South Africa, DTPS, 2016, p. 3). Through the 2016 White Paper, the government seeks to create a Digital Development Fund, the focus of which will be on universal access projects and universal service subsidies for members of identified segments of society (South Africa, DTPS, 2016, p. 33). This implies an intent to continue with public access ICT4D programmes such as public information terminals or kiosks (Oyedemi, 2009; Stillman et al., 2011), multipurpose community centres (Gomez et al., 2012; Mbatha, 2016; Osman \& Tanner, 2017), and free public Wi-Fi (Du Bois \& Chigona, 2018).

As a consequence of the enabling policy environment, there are currently several public access ICT4D programmes across the South African landscape. The extant literature indicates that several of these programmes have been the subject of research over an extended period of time. Table 1 provides an overview of such research, which demonstrates the varying perspectives from which public access programmes have been studied in this country.

TABLE 1 A selection of ICT4D research in South Africa over the past decade

\begin{tabular}{|c|c|}
\hline Author/s, Date & Findings \\
\hline Chigona et al. (2005) & $\begin{array}{l}\text { Libraries have established reputations, which acted like a "local champion" of communal computing facilities (CCFs). CCFs } \\
\text { must be tailored within local contexts and should not be compliant to external objectives and should be people-focused, } \\
\text { not technology-focused. }\end{array}$ \\
\hline Chigona (2007) & $\begin{array}{l}\text { Used a qualitative interpretive approach to investigate relationship between host institutions and communal computing } \\
\text { facilities. A number of advantages and disadvantage are highlighted. }\end{array}$ \\
\hline $\begin{array}{l}\text { Van Rensburg et al. } \\
\text { (2008) }\end{array}$ & $\begin{array}{l}\text { Developed a business model of "Infopreneurs" in the Sekhukhune Living Lab to implement collaboration tools and services } \\
\text { to communities. }\end{array}$ \\
\hline James et al. (2008) & $\begin{array}{l}\text { Descriptive research on the public access to information landscape in South Africa using questionnaires for users and } \\
\text { operators. }\end{array}$ \\
\hline Andries (2009) & $\begin{array}{l}\text { Investigated the Smart Cape Access Project at a single site to ascertain how it is utilised as a tool for economic and } \\
\text { personal development. }\end{array}$ \\
\hline Rhodes (2009) & $\begin{array}{l}\text { Used actor-network theory to trace the implementation trajectory of a telecentre in Sekhukhuneland and found that the } \\
\text { telecentre "suffered from a trajectory failure." }\end{array}$ \\
\hline Chigona et al. (2010) & $\begin{array}{l}\text { Used stakeholder management to analyse the SmartCape Access project. The study highlighted the fact that there was no } \\
\text { formal stakeholder management undertaken during the planning stages. There were also many missed opportunities for } \\
\text { stakeholder management throughout the project's lifecycle. }\end{array}$ \\
\hline $\begin{array}{l}\text { Pather and Gomez } \\
\text { (2010) }\end{array}$ & $\begin{array}{l}\text { In comparing libraries, telecentres, and cybercafes in South Africa and Brazil, the authors found that South Africa generally } \\
\text { ranked lower than Brazil using the "Real Access" framework. }\end{array}$ \\
\hline Chigona et al. (2011b) & $\begin{array}{l}\text { Explored the use of shared access points in the wake of the increasing diffusion and usage of mobile technology and found } \\
\text { that there are economic, social, and psychological benefits from using the facilities, as well as challenges that limit use } \\
\text { and benefits from the usage. }\end{array}$ \\
\hline $\begin{array}{l}\text { Walton and Donner } \\
\text { (2012) }\end{array}$ & $\begin{array}{l}\text { The study assesses and describes the interplay between public PC-based Internet access and private mobile-based access } \\
\text { amongst teenagers. }\end{array}$ \\
\hline $\begin{array}{l}\text { Pade-Khene and Sewry } \\
\text { (2012) }\end{array}$ & Developed a rural ICT comprehensive evaluation framework to be applied throughout the progression of an ICT4D project \\
\hline $\begin{array}{l}\text { Donner and Walton } \\
\text { (2013) }\end{array}$ & $\begin{array}{l}\text { Highlighted the ongoing importance of public access centres in the era of mobile Internet using interviews, focus groups, } \\
\text { and questionnaires. }\end{array}$ \\
\hline Gomez et al. (2012) & $\begin{array}{l}\text { Finds that entrepreneurial initiatives fulfil an increasingly important niche in public ICT access landscape and cybercafés } \\
\text { can be an effective way to overcome the shortcomings of telecentre experiences. }\end{array}$ \\
\hline $\begin{array}{l}\text { Mamba and Isabirye } \\
\text { (2015) }\end{array}$ & $\begin{array}{l}\text { Based on a case study; presents as findings a framework on how the success rate of ICT4D projects in rural settings can be } \\
\text { improved. }\end{array}$ \\
\hline $\begin{array}{l}\text { Tabassum and Yeo } \\
\text { (2015) }\end{array}$ & $\begin{array}{l}\text { Argues that traditional measurable impacts of telecentre are not sufficient and proposes an alternative qualitative } \\
\text { methodology to evaluate the intangible impacts of ICTs perceived by its nonusers. }\end{array}$ \\
\hline Mbatha $(2015,2016)$ & $\begin{array}{l}\text { Investigated the usage and types of ICTs accessible to community members and argues for the development of enabling } \\
\text { policy and legislative frameworks to provide for the training to ensure effective use of ICTs. }\end{array}$ \\
\hline $\begin{array}{l}\text { Attwood and May } \\
\text { (2015) }\end{array}$ & $\begin{array}{l}\text { Based on a case study; identifies six amendments to the choice framework (Kleine, 2013) to enhance the usefulness of its } \\
\text { application. }\end{array}$ \\
\hline $\begin{array}{l}\text { Osman and Tanner } \\
\text { (2017) }\end{array}$ & $\begin{array}{l}\text { Found that in telecentre programmes services, computer training and entrepreneurial support positively influence and } \\
\text { contribute to the perceived psychological empowerment of "underserved" community members. }\end{array}$ \\
\hline $\begin{array}{l}\text { Du Bois and Chigona } \\
\text { (2018) }\end{array}$ & $\begin{array}{l}\text { Investigated how free public } \mathrm{Wi}-\mathrm{Fi} \text { augments telecentres and found that the activities undertaken by users at telecentres } \\
\text { are similar to those using Wi-Fi. }\end{array}$ \\
\hline
\end{tabular}

Abbreviations: ICT, information and communications technology; ICT4D, information and communication technologies for development. 
The research summarised in Table 1 indicates a plethora of findings, across a range of issues, in respect of the public access ICT4D landscape in South Africa over the past decade. These range from studies that provide a general overview of the landscape (eg, James, Finlay, Jensen, Neville, \& Pillay, 2008; Pather \& Gomez, 2010) to issues that sought to determine factors of success (eg, Chigona et al., 2005; Mamba \& Isabirye, 2015) to those that highlight the implementation challenges (eg, Chigona, Roode, Nabeel, \& Pinnock, 2010).

Those studies that provide some insight into factors of success begin to set out some basis to respond to the problem of evaluation described in Section 1 of this paper. Only one study sets out to develop an evaluation framework. Pade-Khene and Sewry (2012) propose a Rural ICT Comprehensive Evaluation Framework (RICT-CEF), which encompasses the key domains of evaluation that should be applied throughout the progression of an ICT for development project. This framework is based on typical project development phases, traversing an initial baseline assessment and a needs assessment until a final scalability assessment is undertaken. The RICT-CEF framework does provide for an evaluation phase, which considers outcome assessment (Pade-Khene \& Sewry, 2012, p. 3). However, there is no detail on what these outcomes might be. Another paper that does lend itself to the evaluation conundrum is the study by Tabassum and Yeo (2015). They advance the position of Gomez and Pather (2012) and bring forth a perspective of what intangible benefits in telecentre programmes are. Their study, however, is not based on empirical evidence but draws on the extant literature to derive a list of intangible benefits that have been identified in public access programmes.

There is thus a gap in the literature in terms of an empirically based foundation for understanding public access ICT4D benefits, be they tangible or intangible. This underscores the relevance of the problem and the research question articulated in Section 1 of this paper. The remainder of the literature examines the issues in relation to ICT4D evaluation in further detail.

\section{2 | ICT4D evaluation}

The G8 meeting of 2002 was the first international forum where governments formally recognised the role of ICT in enabling social and economic development (Rothenberg-Aalami \& Pal, 2005). At the WSIS in Geneva in 2003 and Tunis in 2005, there was a broad consensus amongst governments for an agenda to leverage ICT for support of socio-economic development. The Millennium Declaration too acknowledged that ICTs are important in achieving the overall MDGs, for example, by improving delivery of education and healthcare or making government services more accessible (ITU, 2006). In the post-2015 agenda discussions, the growing importance of ICTs in attaining goals $\$ 5 b, 9 c$, and 17.8 are still evident (ITU, 2013).

\subsubsection{Challenges with evaluation}

Since WSIS, a growing body of knowledge has been criticised by researchers who argue that the application of ICT to address fundamental societal issues in different cultures, different socio-economic conditions, and for a range of desired outcomes is often not successful (Cordell \& Romanow, 2005, p. 20; Pigg \& Crank, 2004, p. 22; Williams, Sligo, \& Wallace, 2005, p. 21). The sustainability of ICT initiatives in communities has also proved to be problematic (Ashraf, Swatman, \& Hanisch, 2007) and projects costly.

Heeks (2007) indicated that ICT4D outputs

i) reflect a bias to action and not to knowledge,

ii) are descriptive, and

iii) are not analytical enough.

Lee, Jang, Ko, and Heeks (2008, p. 2) reported a lack of hard evidence regarding the economic and social impact on development of ICT4D initiatives and voiced concern that the impacts are not universally beneficial (Lee et al., 2008, p. 2).

Sufficient insight into methods of evaluating the effectiveness of these ICT projects on socio-economic development is lacking (Ashraf, Swatman, \& Hanisch, 2008, p. 3). Various authors confirmed the finding by Rothenberg-Aalami and Pal (2005, p. 7) that there are no commonly agreed-upon techniques to assess the impact of rural telecentres (Ashraf et al., 2008; Colle, 2005; Grunfeld, 2007; Hedberg, 2010; Heeks, 2007; Lee et al., 2008; Parthasarathy \& Srinivasan, 2006; Pather \& Uys, 2010; Sey \& Fellows, 2011).

\subsection{2 | The need for improving ICT4D assessment}

The problem of how to identify the benefits of public access initiatives is now being faced by governments and NGOs, which is similar to the situation that the business sector has faced over the last 40 to 50 years. It is not a simple task to conceptualise and measure the value of social development in the ICT4D context. Early in the 21st century, O'Neil (2002, p. 77) argued that in community informatics, the focus of project

The group of eight (G8) major industrialised nations: France, Germany, Italy, Japan, Britain, USA, Canada, Russia

${ }^{\S}$ Goal 5b: enhance the use of enabling technologies, in particular, ICT, to promote women's empowerment. Goal 9c: significantly increase access to ICT and strive to provide universal and affordable access to Internet in LDCs by 2020. Goal 17.8: enhance the use of enabling technologies, in particular, ICT. 
evaluations was often on nonmeasurable (intangible) social factors. Outcomes are indirect, making the evaluation of impacts of technology projects difficult (Merkel et al., 2005, p. 164). Parthasarathy and Srinivasan (2006, p. 3) warned against applying easy to measure data for well-defined indicators to measure social development factors. Other authors also reported finding little evidence of measurable (tangible) impacts of ICT4D projects (Gomez, 2008; Gomez \& Pather, 2012; Gomez, Reed, \& Chae, 2013, p. 37; Hedberg, 2010; Sey \& Fellows, 2011, p. 189).

Evaluation methods that are in use vary from longitudinal studies investigating the effects of the Internet on social capital (Gaved \& Anderson, 2006) to quantifying performance (the impact of ICT projects) by way of a system measuring inputs, outputs, and outcomes.

\subsection{A gap in frameworks for measuring ICT4D programmes}

The extant literature indicates that for many years, there have been no formal evaluation frameworks in use in the ICT4D context. This could be because the users of ICT4D initiatives are not part of a formal or structured project and have their own motivation for using ICT. Although a number of authors have devised frameworks, none of them evaluates or identifies the nature of the benefits or the benefits accrued by users of public access centres (PACs).

Authors highlighted existing gaps in the knowledge of evaluation of benefits and the nature of these benefits and acknowledged the complexity of measuring social development in ICT4D (Ashraf et al., 2007, 2008; Gomez, 2008; Gomez et al., 2013; Gomez \& Pather, 2012; Grunfeld, 2007; Sey \& Fellows, 2011). The focus of evaluation attempts shifted to the concept of human development. Sen (2001) devised the capability approach (CA), which inspired ICT4D researchers to view human development as a process of expanding a person's freedoms (capabilities) and choice. Several authors in community informatics and ICT4D research domains have applied the CA philosophy in their research and subsequently included it in evaluation frameworks. Amongst them are as follows:

- Alsop and Heinsohn (2005) devised a framework to evaluate the impact of ICT4D initiatives on development outcomes and empowerment.

- The sustainable livelihoods framework (SLF) models various capitals to livelihood outcomes (Parkinson \& Lauzon, 2008; Parkinson \& Ramírez, 2007).

- Kleine (2009) developed the choice framework, on the basis of Sen's CA and the SLF, which evaluates the development of personal freedom.

- Grunfeld, Hak, and Pin (2011) developed the capability, empowerment, and sustainability virtuous spiral (CESVS) framework, which was designed to investigate and understand the processes associated with the realisation of the benefits of ICT.

- The ICT impact chain developed by Gigler (2011) evaluates the impact of ICT in terms of the CA.

- Hatakka and De (2011) evaluated expanding human capabilities and functionings as key to development.

- Kivunike (2014) used the framework of Hattakka and De but modified it to include 'choice' as an achieved functioning.

Evaluation methods from other domains include Hickey and Mohan's participatory monitoring and evaluation approach (Hickey \& Mohan, 2004), and the SLF approach (Parkinson \& Lauzon, 2008; Parkinson \& Ramírez, 2007). However, an analysis of the literature indicates a preference for the application of the CA (Sen, 1990) as a suitable lens for understanding the developmental impacts of ICT4D initiatives on communities.

In summary, even though there are many studies examining different aspects of ICT related to development, there are still gaps in the knowledge relating to the benefits of ICT initiatives. These gaps include deeper understanding of benefits and their nature, as well as how these benefits can accrue to development (Grunfeld, 2007) There are therefore various research opportunities and questions to be asked in the ICT4D domain, of which the evaluation of ICT benefits is one of the most pressing.

\section{3 | RESEARCH APPROACH}

During the literature analysis, it became clear that ICT4D research processes had to follow an alternative approach to the methods used in the information systems research context and business or education evaluation research. Initially, ICT4D researchers employed approaches from these fields and came to the same conclusion. The context of ICT4D initiatives deployed in communities require an alternative research approach since communities are not structured and do not work towards some unified goal and the benefits accrued by communities are often not measurable.

\section{1 | Case study design}

The research adopted an overarching case study approach, which, according to Yin (2009, p. 4), provides a basis "to understand complex social phenomena". Yin (p. 63) adds that data collected for these designs can be stronger and richer than data collected by one method alone. Case studies can increase knowledge where the focus of the research is current events within an organisation or entity. As such, the study was designed 


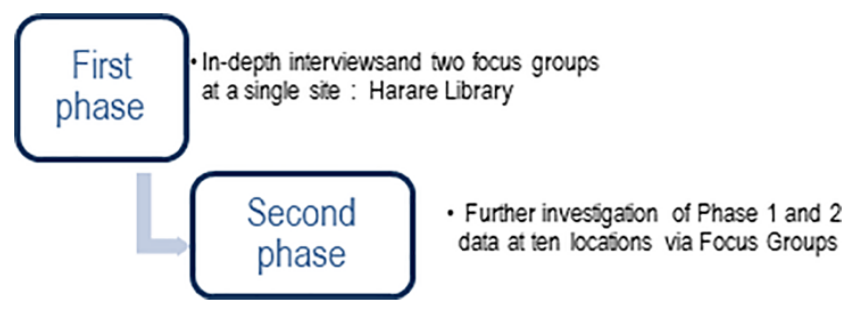

FIGURE 1 Data collection phases

TABLE 2 Focus group venues

\begin{tabular}{lcr} 
Focus Group Venue & Frequency & Percent \\
1. Khayelitsha Centre & 14 & 9.3 \\
2. Khayelitsha Site B library & 16 & 10.7 \\
3. Khayelitsha Shawco & 14 & 9.3 \\
4. Khayelitsha Harare Library & 15 & 10.0 \\
5. Khayelitsha TAC Office & 17 & 11.3 \\
6. Mitchells Plain Town Centre & 15 & 10.0 \\
7. Mitchells Plain Family Centre & 16 & 10.7 \\
8. Mitchells Plain Baptist Church & 14 & 9.3 \\
9. Mitchells Plain Town Centre & 13 & 16 \\
10. Mitchells Plain Family and Youth Centre & 16 & 10.7 \\
Total & 150 & 100.0 \\
\hline
\end{tabular}

using interviews, focus groups, and a short survey. Case studies have often been used in similar studies to this research such as Akinsola, Herselman, and Jacobs (2005), Alao (2010), and Attwood and May (2015).

\section{2 | The SmartCape programme of PACs: case study context}

The selected case for this study is the SmartCape** project, which involves installing computers in libraries and making free Internet available to the citizenry. This initiative was launched throughout the City of Cape Town shortly before the inception of this study. Within 1 year, it had registered almost 38000 users. Because of this rapid uptake, it was deemed a suitable case study. The SmartCape programme has the following three primary goals:

- to provide free public access to computers and the Internet;

- to prove that open source software is affordable, appropriate technology for a public service digital divide initiative; and

- to increase opportunities for members of disadvantaged communities (City of Cape Town, 2010, 2015; Infonomics, 2003, p. 5):

\section{3 | Collection of data}

Qualitative and quantitative data were collected by the authors and research assistants during two phases (Figure 1) in two of the largest communities in which the SmartCape was deployed, viz, Khayelitsha and Mitchells Plain. Access to users in the libraries was negotiated with the Library Marketing and Research department of the City of Cape Town. The focus groups were moderated by the authors.

Phase 1:) An access point of the SmartCape initiative that was established about the same time as the inception of this study was selected as a site for in-depth investigation for this research. This was an ICT centre within the newest library at the time, the library in Harare, Khayelitsha, in the City of Cape Town. Data were collected by interviewing 20 users at this site. Following the interviews, two focus groups were conducted with 14 users from the same library to allow for further exploration of the interview data.

Phase 2:) With the data from phase 1 at hand, we conducted further investigation into the initial themes that emerged from the data. These themes included positive and negative issues regarding "Internet access" and "how Internet can bring hope to their families." These themes had emerged from the interviews and focus groups from the first phase of data collection through the qualitative analysis process (see Section 3.4). Therefore, 10 further sites were selected, at which 150 community members participated in focus groups as depicted in Table 2.

**Also rendered as "Smart Cape" or "Sm@rtCape." 


\subsection{1 | Development of instruments}

Overall, the data collection strategies entailed questions that focussed on computer and Internet knowledge, frequency of visits to the library and ICT centre, general usage of the computers and the Internet in the centre, and perceptions of the impact of the accessibility to the Internet. Demographical questions gave an indication of the socio-economic status of the participants. Specific aspects that informed the design of each of the instruments are as follows:

- Interview and focus group questions in phase 1 related to the biographical background of each participant, their type of community, their knowledge (previous or current) of computers and the Internet, the frequency of their visits to the library and ICT centre, their general usage of the computers and the Internet in the centre, and their perceptions of the impact of being able to access the Internet on their lives.

- The phase 2 focus group schedules included only three questions that related to (a) the participants' perceived challenges in accessing the Internet, (b) their view of how helpful it would be to have access to Internet from their home, and (c) their perspective regarding how having access to the Internet brings hope to them and their families.

\section{4 | Data analysis}

The interviews and focus group sessions of the first phase of data collection were recorded and transcribed as readable text. The interviews took an average of about 2 hours each to transcribe, and it resulted in total of 120 pages of transcripts. The data from two focus groups, which were transcribed and then translated from isiXhosa ${ }^{\dagger \dagger}$ into English, comprise about 70 pages. The transcripts of the 20 interviews and two focus groups of the first phase of data collection were subjected to coding and content analysis in Atlas.ti, which involves a systematic analysis of the text (Bhattacherjee, 2012, p. 115) as raw data and transforming it into a standardised form (Babbie, 2010, p. 338) by selecting segments or chunks of text and assigning a 'code' to it. Coding can be based on the themes from a conceptual framework or on new emerging themes in the text.

The data from interviews and the first two focus groups (phase 1) were analysed as a single set of evidence. This yielded an initial set of findings, which were then probed in the next phase of analysis (see Appendix). These findings were the basis for developing the questions for the next phase of data collection. Thus, the instrument for the 10 focus groups examined (a) challenges in accessing Internet, (b) helpfulness of having Internet at home, and (c) hopefulness regarding access to the Internet.

The data from the 10 focus group sessions of phase 3 comprised response cards to the focus group questions, which were completed and then grouped by participants during the focus group. This was then subjected to further analysis.

By grouping the codes together, themes were constructed, and relationships between these themes were identified using a co-occurrence matrix, which is a symmetrical matrix of frequencies of themes in the data that occur together (Atlas.ti, 2014, pp. 21, 259). This matrix is similar to a correlation table used in statistical analysis. A co-occurrence index, called "c-coefficient," which is an indication of the strength of the relationship between the two codes, can also be derived from the co-occurrence matrix (Atlas.ti, 2014, pp. 21, 259; Coxon, 1999, p. 68).

This was followed by the statistical techniques called cluster analysis and multidimensional scaling (MDS).

\section{4 | RESULTS AND FINDINGS}

\subsection{The nature of the benefits of ICT4D initiatives in local communities}

From the ontology of the critical realist (CR) paradigm, a reality can be investigated by considering multiple perceptions of this reality (Healy \& Perry, 2000). Both positivist and interpretivist tools and techniques to investigate a phenomenon are acceptable in the CR paradigm (Pather \& Remenyi, 2005), which allowed this research study to utilise qualitative and quantitative research methodologies to explore perceptions of benefits from community members who are users of the PACs.

The empirical data provided a rich insight into the benefits of PACs to communities. Findings indicated that the primary benefits to SmartCape users are the ability to connect with people, business, government, and friends through email and to apply online for employment and studies. Access affords the users the ability to conduct day-to-day business activities and to have increasing choices, opportunities, and capabilities, which, in turn, lead to increasing self-esteem and self-efficacy. A general perception of a "changed life" with regular access emerged together with the notion of hope for a better future and expressions of aspirations of making use of new opportunities that access to the Internet is making possible (Uys \& Pather, 2016).

The main themes of benefits that emerged are presented in Table 3.

\footnotetext{
${ }^{\dagger}$ siXhosa is one of 11 official languages in South Africa.
} 
TABLE 3 Themes of benefits

\begin{tabular}{ll} 
Theme & Description \\
\hline Easier learning opportunities & Opportunities for online applications and study \\
\hline Economic freedom & Saving of money in various ways \\
\hline Social capital & Making more connections with people \\
\hline Enhanced empowerment & Enabler to navigate life according to own choosing \\
\hline Increased agency & Self-efficacy and self-esteem \\
\hline Community involvement & Ease of community involvement enabled through the access and use of the ICT centre \\
\hline Increased ICT skills & Enables more effective use of ICT \\
\hline Aspiration and hope & Hope is a capability that assists people to navigate their daily life, and it can fuel aspirations \\
\hline $\begin{array}{l}\text { More and new opportunities } \\
\text { More and new communication }\end{array}$ & There are more useful "things to do," as well as business and employment opportunities \\
& Easier individual and group communication, made possible by using email and other social networking \\
Evidence of changed life & sites \\
More choice & New opportunities and activities are possible \\
Increased English reading and language & Improved choices specifically in their daily routine and in study choices \\
skills & Deemed important in the communities where English is at least the second language
\end{tabular}

Abbreviation: ICT, information and communications technology.

\subsection{Interrelationships between themes}

The co-occurrences of themes points to relationships among themes. An example of such a table can be seen in Figure 2. The theme "empowerment" appeared 63 times in conjunction with a comment on ICT skills and 106 times in conjunction with ICT usage.

The strengths of these relationships are measured by the c-coefficients, which are given in Table 4.

The c-coefficient between ICT skills and empowerment is 0.55 , which can be seen as a moderately strong relationship between gaining ICT skills and empowerment.

The co-occurrences were subjected to a hierarchical cluster analysis to create a proximity matrix, consisting of squared (Euclidian) distances and utilised as dissimilarities (Leydesdorff \& Vaughan, 2006, p. 6). These are further analysed using MDS, which generates a set of coordinate pairs for each of the themes. From these coordinates, a scatter plot (see Figure 3 ) is constructed that shows the relative positions of the themes. Themes that often occur together in the interviews, and thus in the data, are in a close "relationship" with each other and will lie close together

\begin{tabular}{|l|r|r|r|r|r|r|}
\hline & Agency & Empowerment & Opportunity & Changed Lie & Choice & Communication \\
\hline Agency & 0 & 23 & 9 & 6 & 1 & 2 \\
\hline Empowerment & 23 & 0 & 13 & 20 & 8 & 0 \\
\hline Opportunity & 9 & 13 & 0 & 8 & 14 & 1 \\
\hline Changed Life & 6 & 20 & 8 & 0 & 5 & 0 \\
\hline Choice & 1 & 8 & 14 & 5 & 0 & 2 \\
\hline Communication & 2 & 0 & 1 & 0 & 2 & 0 \\
\hline Economic Freedom & 17 & 30 & 17 & 11 & 15 & 23 \\
\hline Hope & 16 & 10 & 4 & 2 & 2 & 0 \\
\hline ICT Skills & 15 & 63 & 9 & 10 & 3 & 0 \\
\hline ICT Usage & 52 & 106 & 36 & 25 & 22 & 23 \\
\hline
\end{tabular}

FIGURE 2 A few rows of a co-occurrence table

TAB LE 4 Relationships between themes

\begin{tabular}{lll} 
& Empowerment & ICT Usage \\
\hline ICT skills & 0.55 & \\
\hline ICT usage & 0.31 & 0.33 \\
\hline Economic freedom & & 0.33 \\
\hline Learning opportunities & 0.2 & 0.33 \\
\hline Social capital & & \\
\hline
\end{tabular}

Abbreviation: ICT, information and communications technology. 
FIGURE 3 Multidimensional scaling (MDS) two-dimensional scatter plot showing the relationship between the themes

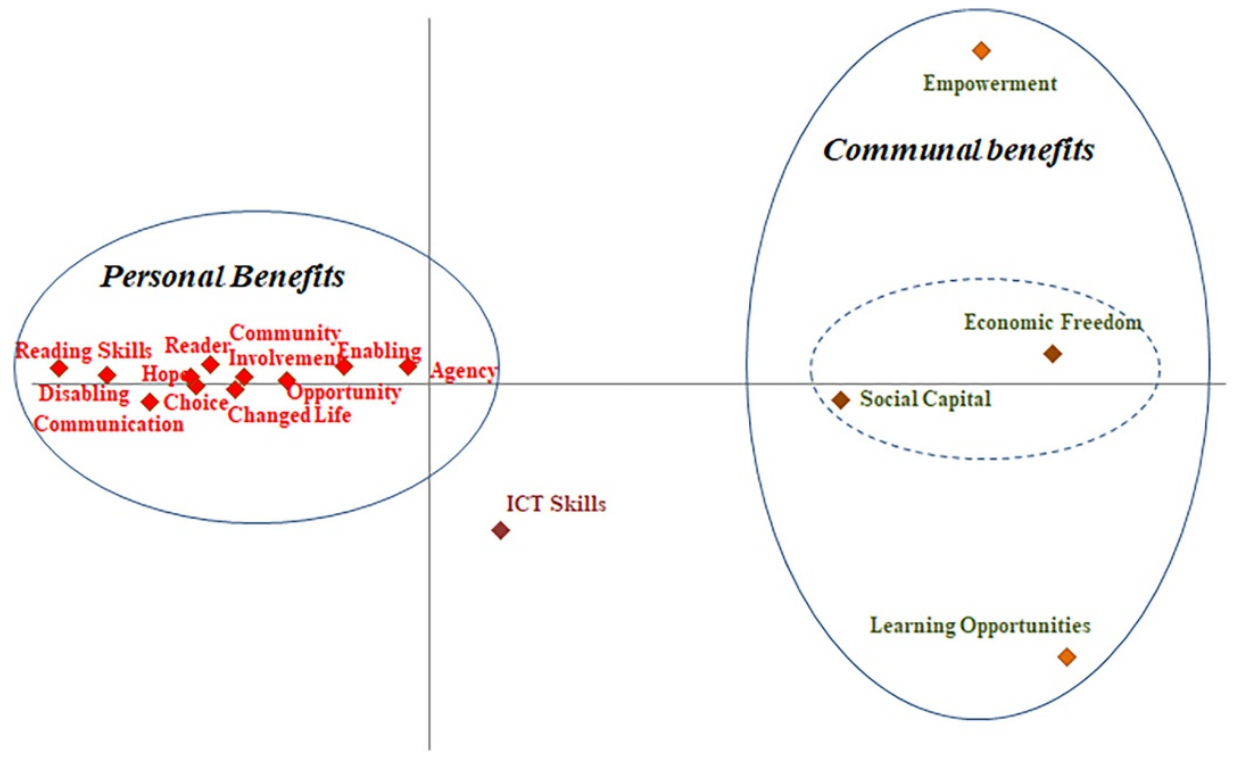

on the scatter plot (Leydesdorff \& Vaughan, 2006, p. 4). The SPSS statistical analysis technique called PROXSCAL is used to obtain the dimensions of each object on the plot.

The "fit" of the model is measured by "stress" values (Table 5), which indicates badness-of-fit, since higher values shows poorer fit (Sturrock \& Rocha, 2000, p. 50).

Stress measures between 0.025 and 0.05 shows a very good fit of the model.

The final coordinates for the two-dimensional scatter plot calculated by MDS is given in Table 6 .

The scatter plot in Figure 3 demonstrates clusters of themes that are closely related to each other. The real numerical values of the coordinates of the objects are only important to locate the object on the plot but have no other statistical meaning.

An assessment of the scatter plot indicates that the themes congregate in two areas: one to the left side of the vertical axis and the other to the right side of the vertical axis (Table 7).

After a closer inspection, the first group of themes was labelled as a group of personal benefits, and the second group of themes was labelled as a group of communal benefits.

The expansion of ICT skills, situated on its own in between these two groups on the scatter plot, can belong to both groups and influences both groups, since ICT skills "facilitate" the occurrences of other benefits.

The benefits listed in the personal benefits group are mostly intangible benefits, with the possible exception of "reading skills." Regarding the benefits listed in the communal benefits group, "economic freedom" and "social capital" can be seen as tangible benefits since economic freedom in this study referred to the financial saving by using the ICT centre and the expansion of employment and business opportunities. Social capital referred to the meeting of new friends and the reconnecting with friends and family with whom the users have lost touch.

Thus, the horizontal axis represents the level of the benefit (ie, the personal or the communal), and the vertical axis represents the measurability. The benefit of learning opportunities, including information found and knowledge gained, are found a distance below the horizontal axis, and empowerment (a nonmeasurable benefit), which includes individual as well as group empowerment, is found high above the horizontal axis. Some

TABLE 5 Stress measures

$\begin{array}{lr}\text { Badness-of-fit } & 0.00155 \\ \text { Normalised raw stress } & 0.03935^{\mathrm{a}} \\ \text { Stress-I } & 0.06564^{\mathrm{a}} \\ \text { Stress-II } & 0.00293^{\mathrm{b}} \\ \text { S-Stress } & 0.99845 \\ \text { Goodness-of-fit } & 0.99923 \\ \text { Dispersion Accounted For (D.A.F.) } & \end{array}$

Note. PROXSCAL minimises normalised raw stress.

${ }^{\mathrm{a} O p t i m a l}$ scaling factor $=1.002$.

${ }^{\mathrm{b}}$ Optimal scaling factor $=1.000$ 
TABLE 6 Final coordinates

\begin{tabular}{|lcc|}
\hline & Dimension 1 & Dimension 2 \\
\hline Learning opportunities & 1.200 & -0.523 \\
\hline Economic freedom & 1.174 & 0.057 \\
\hline Empowerment & 1.038 & 0.640 \\
\hline Social capital & 0.775 & -0.031 \\
\hline ICT skills & 0.135 & -0.281 \\
\hline Agency & -0.040 & 0.034 \\
\hline Enabling & -0.162 & 0.034 \\
\hline Opportunity & -0.268 & 0.007 \\
\hline Community involvement & -0.351 & 0.014 \\
\hline Changed life & -0.365 & -0.010 \\
\hline Reader & -0.412 & 0.037 \\
\hline Choice & -0.438 & -0.004 \\
\hline Hope & -0.451 & 0.013 \\
\hline Communication & -0.528 & -0.035 \\
\hline Disabling & -0.608 & 0.017 \\
\hline Reading skills & -0.699 & 0.029 \\
\hline Learning opportunities & 1.200 & -0.523 \\
\hline Ahe & & \\
\hline
\end{tabular}

Abbreviation: ICT, information and communications technology.

TABLE 7 Theme groups

\begin{tabular}{|lll}
\hline First Theme Group & & Second Theme Group \\
\hline Agency & Choice & Learning opportunities \\
\hline Enabling & Hope & Economic freedom \\
\hline Opportunity & Communication & Empowerment \\
\hline Community involvement & Disabling & Social capital \\
\hline Changed life & Reading skills & \\
\hline Reader & & \\
\hline
\end{tabular}

elements of social capital (number of new connections made) and economic freedom (money saved, more employment opportunities) are measurable. However, both have nonmeasurable elements. For example, social capital has elements that describe deepening of older relationships, and having free access to information and knowledge through free access to the Internet at the ICT centre are nonmeasurable benefits.

\section{DISCUSSION OF FINDINGS}

The nature of the benefits that were identified are both tangible (measurable) and intangible (nonmeasurable). Included in the measurable benefits are economic benefits and increased skills in reading, language, and ICT. The benefit of saving money was a recurring theme in the interview and focus discussions. With regards to the intangible benefits, the ability to connect or reconnect with people, including family, friends, businesses, and government, emerged as an important benefit. Notable also are the feeling of increased empowerment in both individuals and the community of users and the increased ability to make use of new opportunities and choices (agency). According to Sen (2001), cited in Alkire and Deneulin (2009a, p. 31), agency is the "ability to pursue goals that one values and has reason to value," and the freedom to make use of opportunities is an element of capabilities (Alkire \& Deneulin, 2009a, p. 32).

By investigating co-occurrences of the themes of the qualitative data, a relationship between the perception of empowerment and increased ICT skills (Table 3) emerged. In addition, a relationship between ICT usage and financial benefits, learning opportunities, and social capital became apparent. A relationship between empowerment and learning opportunities was also evident. This finding thus emphasises the notion that using ICT and developing the associated skills lead to more use of ICT, which has the concomitant benefit of producing a feeling of hope. This in turn 
acts as a catalyst that enables people to expand their resources and to navigate their daily journey. This confirms the appeal by ICT4D researchers to evaluate nonmeasurable as well as measurable impacts and benefits (Gomez et al., 2013; Gomez \& Pather, 2012; Grunfeld et al., 2011).

\section{1 | A framework of benefits of ICT4D initiatives}

During the initial stage of the study, a framework was developed as an early attempt to guide the analysis of the empirical phase of the study. This early framework did not include the achieved capability of hope or of increased agency, which have emerged as intangible benefits in this study. Thus, a modification of that framework was required to include these emergent benefits. The importance of these emergent benefits is that both are enabling capabilities that assist people in identifying and making use of opportunities presented to them.

The emergent benefit of hope is engendered by the access to technology and use of technology in the PACs in underserved communities. Hope is a nonmaterial construct, extremely important in the realm of well-being and quality of life, although seldom mentioned in quality-of-life research studies (Rustøen, 1995). To understand the concept of hope and the role it plays in the day-to-day lives of people, it is necessary to explain the relationship between hope and aspiration, a nonmeasurable benefit identified by Gomez et al. (2013, p. 38).

\subsection{1 | Expression of aspiration}

Aspiration describes the hope-a looking forward to-that one has to be or to achieve something. Appadurai (2004), cited in Pal (2008), makes a case for aspiration to be an important construct in development. Pal states that "both the determinants of aspiration and their impacts on individual behaviour are important" in the realm of ICT4D. Freistadt, Pal, and da Silva (2009) reported that the aspect of aspiration was one of the impacts of access to ICT centres that culminated in a "strong aspirational discourse" among graduates of a training course at an ICT centre. Individuals with aspirations focus their time and energy on future accomplishment (Gomez et al., 2013, p. 38).

When aspirations stem from increased human capabilities in association with ICT use and not purely from own personal desires, they translate into a "navigational capacity," thus strengthening agency, and a development outcome (Ray \& Kuriyan, 2010). Ray and Kuriyan (2010) further suggested that the operationalisation of aspiration is informed by three questions:

- Do poor people use existing resources and capabilities differently after exposure to ICT services?

- What is the effect of ICT interventions specifically regarding average or median members of low-income groups?

- Are there measurably new social networks enabled by ICTDs that allow the poor to look beyond their existing windows of aspiration?

These are very similar to the following questions of Ward and Daniel (2006, p. 173) in an investigation into benefits: Are the people doing new things? Are they doing things differently than before? Have they stopped doing things?

Thus, the expression of aspiration brings a very important perspective to the realm of ICT4D in general and the domain of PACs in particular. This importance is borne out by evidence in this study of the enthusiasm in grassroots communities in respect of the ability to find employment. In addition, the excitement at the prospect of commencing or continuing studies and the capability to plan a better future for themselves are elements of aspiration.

\subsection{2 | Hope}

"Hope" is the intangible and elusive beneficial element that is lacking in all the frameworks and all the evaluations of ICT4D initiatives in the extant literature, even though it was alluded to by Gomez et al. (2013, p. 38). Well-being and self-esteem, which lead to empowerment, are directly linked to feelings of hope and aspiration, and hope has been declared a capability (Duflo, 2012, p. 40; Freistadt et al., 2009, p. 10; Parker \& Wills, 2009).

The capability of hope emerged as a critical intangible benefit and provides a very compelling argument for the role of publicly available ICTs in the development of communities.

Since hope emerged in the interviews as a benefit, hope, representing expressions of aspiration, has been included in the proposed framework for benefits as achieved functionings, together with choice and other achievements.

\subsection{3 | The benefits framework}

Following on the various stages of analysis described in the foregoing section, a benefits framework is derived (Figure 4). The framework comprises the elements ICT usage, conversion factors, and opportunities and capabilities and lists the benefits. Each element of the framework is discussed in the following subsections. 


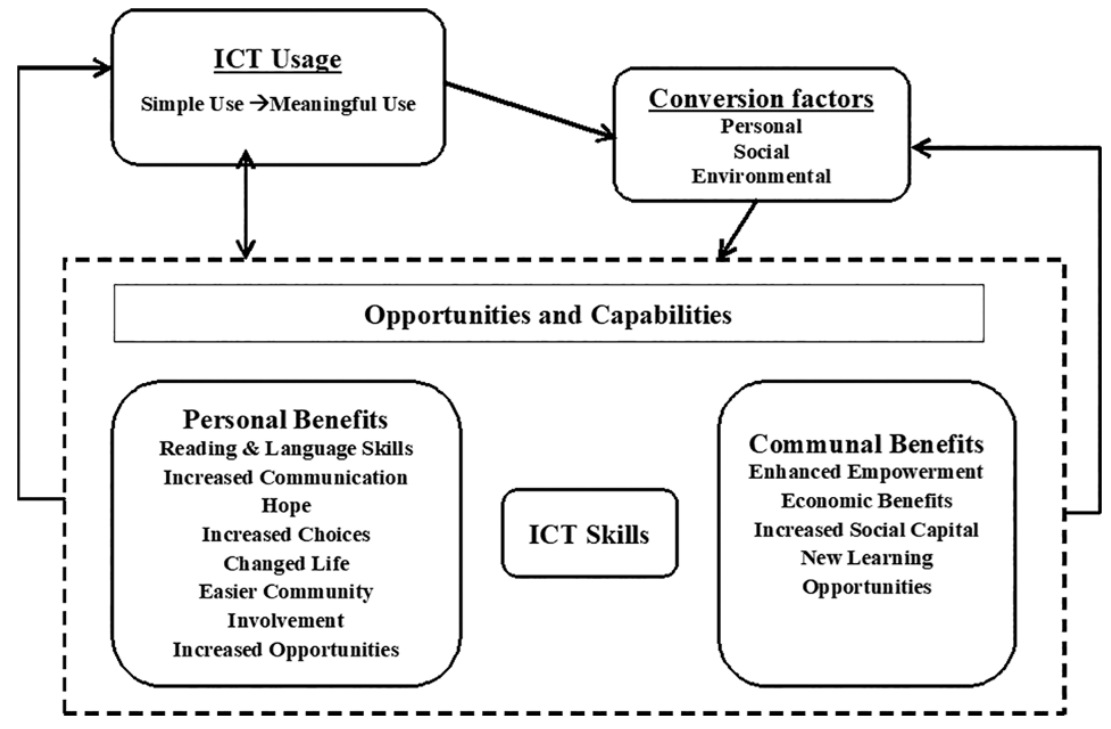

FIGURE 4 Information and communications technology (ICT) benefits framework: public access ICT4D initiatives

TABLE 8 First theme group

\begin{tabular}{ll} 
Agency & Opportunity \\
\hline Community involvement & Changed life \\
\hline Hope & Choice \\
\hline Communication & Reading skills \\
\hline
\end{tabular}

\section{ICT usage}

Access and use of technology by users of the PAC are imperative for both tangible and intangible benefits to be realised. This study found that PAC users increased their frequency of access to ICTs once they experienced a benefit, such as communicating with family or friends, finding new information, registering online to study, or being able to make use of new business opportunities. This, in turn, increases the type of use and new benefit possibilities. Thus, benefits accrued from regular and increased access to technology leads to more meaningful use of ICTs.

\section{Conversion factors}

PAC users expressed satisfaction that the centre is in close proximity to their community, which enabled them to use the facilities without having to travel to the centre and incur expense. The larger number of available computers and the friendly attitude of the library personnel towards new users were also mentioned. However, participants felt that having only 45 minutes per day limited the type of work or communication they needed to do. Network outages were also mentioned as problematic. These are examples of environmental enabling and disabling factors.

A user's personal and social conversion factors can be strengthened by meaningful use of ICTs, which enables the realisation of benefits and enhances a person's capacity to exploit choices and increase capabilities. The findings showed a positive impression of the ICT centre and demonstrated a positive personal reputation of respondents when perceived by their community as a user of the ICT centre.

The conversion factors are included in the framework because of their positive or negative effect on the realisation of benefits.

\section{Opportunities and capabilities}

The benefits received by PAC users all relate to new opportunities and achieved capabilities. These elements are based on the three emerging groups of themes from the data, namely, the personal benefits, the communal benefits, and the increased ICT skills identified by the MDS analysis and the bi-plot.

Personal benefits. Table 8 shows the benefits in the first theme group, namely, personal benefits. These benefits emerged from the data in relation to the impact that the use of the ICT centre has had on the lives of users.

Increased self-esteem and self-efficacy, which are represented by "agency," hope, perception of a changed life, presentation of new opportunities, enhanced communication, increased reading skills, and community involvement opportunities, comprise the list of benefits in the first group.

\footnotetext{
Whis is the current policy of the SmartCape programme to ensure that as many users as possible are able to access the centre.
} 
All of these are benefits to the individual, hence the term "personal benefits." Hope, a novel finding that has emerged as a benefit in this study, is a facilitating and path-finding capability because it influences a person's ability to navigate resources, make the right choices, and make use of opportunities (Uys \& Pather, 2016). Once PAC users realised this benefit, they changed their behaviours and daily routines in order to make full use of the opportunities.

Communal benefits. The second group of benefits relate to new opportunities available to the community of users of the PACs, as evidenced by the participants.

These opportunities, listed in Table 9, are learning and study opportunities, financial opportunities, opportunities to make and foster connections, and the increased perception of empowerment of individuals and the community, through access to the ICT centre and the Internet.

ICT skills. The benefits of increased ICT skills were mentioned by participants in relation to themselves as well as to the community as a whole. Thus, ICT skills is a benefit, but it does not fit into the two previous groups, according to the MDS analysis (Figure 4) in this study. As stated before, increased ICT skills have a positive impact on empowerment, which in turn has a relationship with learning opportunities (Table 4).

\section{2 | Application of the benefits framework}

The framework (see Figure 4) addresses the problem that was the basis of the study. We argued that governments, NGOs, and other agencies in the ICT4D arena, do not (as yet) have frameworks to establish if ICT4D investments are yielding benefits in communities. The framework is therefore useful to governments, NGOs, and others who are incepting and managing PAC programmes. It offers a basis to assess benefits of PAC programmes by pointing to specific metrics in respect of benefits of both a measurable and nonmeasurable nature.

In addition, this framework furthers the academic discourse on operationalising the CA by demonstrating the inclusion of a person's agency and conversion factors that inhibit or enhance utilisation of opportunities and choices in the realisation of benefits. This further demonstrates that the amendments proposed by Attwood and May (2015) in respect of agency are indeed practical.

From a practice perspective, this framework will be useful to donor agencies or project teams and governments to determine the degree of success of their interventions. This includes whether benefits have been produced or not, whether access to ICT to underserved communities has been of value to these communities or not, and to assist in investigating factors that can inhibit or enhance the utilisation of access and ICTs.

Although the benefits framework is derived from a study of a single public access programme in South Africa, it may provide a basis for understanding and evaluating benefits of other similar programmes in other countries. Several countries, especially developed countries, across the world have implemented such programmes and continue to do so.

We therefore recommend that the framework can be tested further by using it to assess the existence of benefits in semirural and rural areas. Future research would be to use the framework to develop more structured instruments to assess public access programmes.

\section{3 | Summary}

The objectives of the study reported in this paper were to understand ICT4D public access initiatives, to identify the nature of the benefits of ICT4D initiatives, and to develop a framework for benefits from ICT4D initiatives. The benefits framework presented in Figure 4 brings together the benefits that can be realised through the access and use of ICTs and the expansion of people's abilities to exploit new avenues and opportunities afforded to them.

In addition to the description of each element presented in the foregoing section, the framework also represents the relationship between all the entities. The double-headed arrows between ICT usage and opportunities and capabilities represent a two-way effect; that is, as basic use of technology changes into more effective and meaningful use, the assumption is that more benefits will become available, which will increase the users' confidence to learn additional ICT skills. Using ICT meaningfully affects conversion factors, which, in turn, affect people's ability to make choices and exploit opportunities. The more people realise benefits, the greater will be their courage to exploit new opportunities. Thus, users of publicly accessible ICT4D interventions make new choices through more effective use of ICTs and convert disabling personal or social conversion factors into enabling factors.

TABLE 9 Second theme group

Learning opportunities

Economic freedom

Social capital

Empowerment 
The benefits framework, informed by the CA, identifies personal and communal benefits of a measurable and nonmeasurable nature. It shows the relationship between benefits accrued and factors inhibiting or enhancing the ability to exploit choices and opportunities. In addition, this framework furthers the academic discourse on operationalising the CA by demonstrating the inclusion of a person's agency and conversion factors that inhibit or enhance utilisation of opportunities and choices in the realisation of benefits.

As found in this study, the human development benefits of access to the Internet at PACs should encourage governments and donor organisations to increase their efforts towards facilitating ICT access by increasing the number and sustainability of PACs. This, in turn, would be a step towards reducing the digital divide in the world.

Undertaking this research study and intertwining its quantitative and qualitative methodologies brought a new understanding and appreciation of the paradigms embracing both these realms. It is envisaged that such intertwined methodologies could find further application in obtaining solutions to research problems, specifically, but not exclusively, in the ICT4D domain.

\section{6 | CONCLUSION}

The main contribution of this study to the body of knowledge of ICT4D evaluation is the development of a framework of benefits in respect of public access ICT4D initiatives. This framework fills the gap in our understanding of the nature of benefits in the ICT4D arena.

In addition, the benefits framework, which emanates from this study, responds to issues that have been raised in the literature. For example, Tabassum and Yeo (2015) made a cogent argument on an alternative qualitative methodology to evaluate the intangible impacts of ICTs perceived by its nonusers. In this regard, this study demonstrates how qualitative data may be used to identify intangible benefits such as hope, increased choices, changed life, and increased agency. Furthermore, this study confirms the findings of Donner and Walton (2013) that the demand for and usage of PACs is not on the decline, even among the mobile-Internet-using teenagers.

Importantly, the framework produced by this study can be used to identify benefits of both measurable and nonmeasurable nature. In addition, this framework furthers the academic discourse on operationalising the CA by demonstrating the inclusion of a person's agency and conversion factors that inhibit or enhance utilisation of opportunities and choices in the realisation of benefits. This further demonstrates that the amendments proposed by Attwood and May (2015) in respect of agency are indeed practical.

Finally, this study produced empirical evidence of the developmental impact of the SmartCape ICT4D programme in Cape Town and thus provided evidence of its value.

Evidence of the developmental impact of ICT and Internet access emerging from this study provides additional motivation for the various levels of the South African Government to maintain and extend the PAC initiatives in order to make available these benefits to the poorer communities. The free access to the Internet and ICTs offered to these communities produces benefits of both measurable and nonmeasurable nature, from the notion of affordability to the acquisitioning of hope, thus fuelling aspirations for a better life with more choices.

\section{ORCID}

Corrie Uys (D) https://orcid.org/0000-0002-0313-3875

\section{REFERENCES}

Akinsola, O. S. A., Herselman, M. E., Jacobs, S. J. (2005). ICT provision to disadvantaged urban communities: A study in South Africa and Nigeria InternationalJournal of Education and Development using Information and Communication Technology, 1(3), 19-23.

Alao, A. O. (2010). The impact of ICTs for agricultural development in the rural community: a case study of Alice, Eastern Cape, South Africa. Unpublished M Soc. Sci Thesis. University of Fort Hare, The University of Fort Hare.

Alkire, S., \& Deneulin, S. (2009). The Human Development and Capability Approach: Freedom and Agency. In S. Deneulin, L. Shahani (Eds.), An introduction to the human development and capability approach: Freedom and agency. 22-48. Sterling, VA: Earthscan.

Alsop, R., \& Heinsohn, N. (2005). Measuring empowerment in practice: Structuring analysis and framing indicators World Bank Policy Research Working Paper (Vol. 3510): World Bank.

Andries, S. W. (2009). The public library and the UNESCO Millennium Development Goals: The case of the Smart Cape access project model at a Cape Town township public library. (M Bibl Mini-thesis), University of the Western Cape, Cape Town. Retrieved from http://etd.uwc.ac.za/xmlui/bitstream/handle/ 11394/2672/Andies_MBIBL_2010.pdf?sequence=1

Appadurai, A., (2004). The capacity to aspire: culture and the terms of recognition. In V. Rao, M. Walton (Eds.), Culture and public action. 59-84. Stanford, CA: Stanford University Press.

Ashraf, M. M., Swatman, P., \& Hanisch, J. (2007). Some perspectives on understanding the adoption and implementation of ICT interventions in developing countries. The Journal of Community Informatics, 3(4), http://ci-journal.net/index.php/ciej/article/view/297/387.

Ashraf, M. M., Swatman, P., \& Hanisch, J. (2008, 9-11 June 2008). An extended framework to investigate ICT impact on development at the micro (community) level. Paper presented at the 16th European Conference on Information Systems (ECIS), Galway, Ireland. 
Attwood, H. E., \& May, J. D. (2015, May). Fine-tuning Kleine's choice framework. In Proceedings of the Seventh International Conference on Information and Communication Technologies and Development (p. 25). ACM.

Babbie, E. (2010). The practice of social research (12th ed.). Belmont, CA: Wadsworth, Cengage Learning.

Bhattacherjee, A. (2012). Social science research: Principles, methods, and practices. Tampa, FA: Open Access Textbooks.

Chigona, W. (2007). Should communal computing facilities cohabit with public facilities? The Journal of Community Informatics, 2(3), http://ci-journal.net/ index.php/ciej/article/view/276/259.

Chigona, W., Lekwane, O., Westcott, K., \& Chigona, A. (2011). Uses, benefits and challenges of public access points in the face of growth of mobile technology. The Electronic Journal of Information Systems in Developing Countries, 49(5), 1-14. https://doi.org/10.1002/j.1681-4835.2011.tb00349.x

Chigona, W., Roode, D., Nabeel, N., \& Pinnock, B. (2010). Investigating the impact of stakeholder management on the implementation of a public access project: The case of Smart Cape. South African Journal of Business Management, 41(2), 39-49. June

Chigona, W., Van Belle, J., Arellano, N., Euvrard, K., Heslop, R. \& Kasper, E. (2005). An evaluation of key determining factors for implementing a successful communal computing initiatives in a disadvantaged community in South Africa. Proceedings of 2nd CIRN Annual Conference, Cape Town. CIRN, 437-447.

City of Cape Town. (2010). Smart Cape: History. Retrieved from http://www.smartcape.org.za/about/history.html

City of Cape Town. (2015). Smart Cape Access. Library and Information Services. Retrieved from http://www.capetown.gov.za/en/Library/Pages/ SmartCapeAccess.aspx

Colle, R. (2005). Memo to telecentre planners. The Electronic Journal of Information Systems Evaluation, 21(1), 1-13.

Cordell, A., \& Romanow, P. A. (2005). Community networking and public benefits. The Journal of Community Informatics, 2(1), 6-20.

Coxon, A. P. M. (1999). Sorting data: Collection and analysis (Vol. 127). Thousand Oaks, CA: Sage. https://doi.org/10.4135/9781412985871

DBE. (2014). Thutong: Support learning space: Dinaledi Schools. Retrieved from http://www.thutong.doe.gov.za/Default.aspx?alias=www.thutong.doe. gov.za/dinaledischools

DOC (2013). Thusong Service Centre: One-stop centre for services and information: Brief background. Pretoria: South Africa Department of Communications Retrieved from. http://www.thusong.gov.za/about/history/index.html

Donner, J., \& Walton, M. (2013). Your phone has Internet-Why are you at a library PC? Re-imagining public access in the mobile Internet era. In P. Kotzé, G. Marsden, G. Lindgaard, J. Wesson, \& M. Winckler (Eds.), Human-computer interaction-INTERACT 2013 (pp. 347-364). Berlin Germany: Springer. https://doi.org/10.1007/978-3-642-40483-2_25

Du Bois, J., \& Chigona, W. (2018). Use of free public Wi-Fi and telecentres in disadvantaged communities in the Western Cape. Development Informatics Association (IDIA 2018), 2.

Duflo, E. (2012). Human values and the design of the fight against poverty. Tanner Lectures 2012. Harvard University, Boston: May 2012.

Freistadt, J. O., Pal, J., \& da Silva, R. H. A. (2009). ICT centers and the access gap to formal higher education for the poor in Brazil. Paper presented at the CIRN Prato Community Informatics Conference 2009, Prato, Italy.

Gaved, M., \& Anderson, B. (2006). The impact of local ICT initiatives on social capital and quality of life Chimera working paper 2006-06 (pp. 1-35). Colchester: Institute for Sociotechnical Innovation and Research at the University of Essex.

Gigler, B.-S. (2011). 'Informational capabilities'-The missing link for the impact of ICT on development. E-Transform Knowledge Platform, World Bank.

Gomez, R. (2008, October 2008). The quest for intangibles: Understanding ICTs for digital inclusion beyond socio-economic impact. Paper presented at the CIRN Prato Community Informatics Conference 2008, Prato, Italy.

Gomez, R., \& Pather, S. (2012). ICT evaluation: Are we asking the right questions? Electronic Journal of Information Systems in Developing Countries, 50(5), 1-14. https://doi.org/10.1002/j.1681-4835.2012.tb00355.x

Gomez, R., Pather, S., \& Dosono, B. (2012). Public access computing in South Africa: Old lessons and new challenges. The Electronic Journal of Information Systems in Developing Countries, 52(1), 1-16. 3 June 2012

Gomez, R., Reed, P., \& Chae, H. Y. (2013). Assessment of community wellness outcomes to measure ICT impact. Paper presented at the Proceedings of the Sixth International Conference on Information and Communications Technologies and Development: Notes-Volume 2.

Grunfeld, H. (2007, December 15-17). Framework for evaluating contributions of ICT to capabilities, empowerment and sustainability in disadvantaged communities. Paper presented at the CPRsouth2 Conference: Empowering rural communities through ICT policy and research, Chennai, India.

Grunfeld, H. (2011). The contribution of information and communication technologies for development (ICT4D) projects to capabilities, empowerment and sustainability: A case study of iREACH in Cambodia (PhD Thesis), Victoria University, Melbourne, Australia. Retrieved from http://vuir.vu.edu.au/ 19359/1/Helena_Grunfeld.pdf

Grunfeld, H., Hak, S., \& Pin, T. (2011). Understanding benefits realisation of iREACH from a capability approach perspective. Ethics and Information Technology, 13(2), 151-172. https://doi.org/10.1007/s10676-011-9268-4

Hatakka, M., \& De, R. (2011, May 2011). Development, capabilities and technology-An evaluative framework. Paper presented at the Proceedings of the 11th International Conference on Social Implications of Computers in Developing Countries, Kathmandu, Nepal.

Healy, M., \& Perry, C. (2000). Comprehensive criteria to judge validity and reliability of qualitative research within the realism paradigm. Qualitative Market Research: An International Journal, 3(3), 118-126. https://doi.org/10.1108/13522750010333861

Hedberg, L. (2010). Telecentre for community development: Evaluation of the Tunjang telecentre, Malaysia. The Journal of Community Informatics, 6(2), $1-16$.

Heeks, R. (2005). ICTs and the MDGs: On the wrong track? Information for Development, Noida, Inde.

Heeks, R. (2007). Theorizing ICT4D Research. Information Technologies and International Development, 3(3), 1-4. https://doi.org/10.1162/itid.2007.3.3.1

Hickey, S., \& Mohan, G. (2004). Participation-From tyranny to transformation?: Exploring new approaches to participation in development. New York, NY: Zed Books.

Infonomics. (2003). Evaluation of the Smart Cape access pilot project: A City of Cape Town digital divide initiative. Retrieved from Cape Town, South Africa: http://www.westerncape.gov.za/text/2003/12/smart_cape_access_project___evaluation_final_report.pdf

ITU. (2006). Measuring ICT for social and economic development. Retrieved from Geneva:

ITU. (2013). Open working group proposal for Sustainable Development Goals. Sustainable development. Retrieved from https://sustainabledevelopment. un.org/sdgsproposal

ITU. (2014). Final WSIS targets review: Achievements, challenges and the way forward. Retrieved from Geneva: 
ITU (2015). The World in 2015: ICT Facts and Figures, Geneva, Switzerland: ITU.

ITU. (2017). ICT facts and figures in 2017. Retrieved from Geneva, Switzerland: https://www.itu.int/en/ITU-D/Statistics/Documents/facts/ ICTFactsFigures2017.pdf

James, T., Finlay, A., Jensen, M., Neville, M. \& Pillay, R. (2008). Public access to information \& ICTs phase II report South Africa. Technology \& Social Change Group, University of Washington Information School.

Keniston, K. (2002, 16 March 2009). IT for the masses: Hope or hype? Retrieved from http://web.mit.edu/ kken/Public/PAPERS/EPW_paper.html

Kivunike, F. N. (2014). Towards an ICT4D evaluation model based on the capability approach. ICTer, 7(1), 1-15.

Kleine, D. (2009, 17-19 April 2009). ICT4what?-Using the choice framework to operationalise the capability approach to development. Paper presented at the 2009 International Conference on Information and Communication Technologies and Development Doha, Qatar.

Kleine, D. (2013). Technologies of choice? ICTs, development and the capabilities approach. Cambridge: MIT Press.

Langa, Z., Conradie, P., \& Roberts, B. (2006). Slipping through the net: Digital and other communication divides within South Africa. In U. Pillay, B. Roberts, \& S. Rule (Eds.), South African social attitudes: Changing times, diverse voices (pp. 131-149). Cape Town: HSRC Press.

Lee, H., Jang, S., Ko, K., \& Heeks, R. (2008). Analysing South Korea's ICT for development aid programme. The Electronic Journal on Information Systems in Developing Countries, 35(2), 1-15. https://doi.org/10.1002/j.1681-4835.2008.tb00239.x

Leydesdorff, L., \& Vaughan, L. (2006). Co-occurrence matrices and their applications in information science: Extending ACA to the web environment. Journal of the American Society for Information Science and Technology, 57(12), 1616-1628. https://doi.org/10.1002/asi.20335

Mamba, M. S. N., \& Isabirye, N. (2015). A framework to guide development through ICTs in rural areas in South Africa. Information Technology for Development, 21(1), 135-150. https://doi.org/10.1080/02681102.2013.874321

Mbatha, B. (2015). Diffusion and adoption of information and communication technologies in South African telecentres: Selected telecentres in KwaZuluNatal. Mousaion, 33(1), 103-120.

Mbatha, B. (2016). Pushing the agenda of the information society: ICT diffusion in selected multipurpose community telecentres in South Africa. Information Development, 32(4), 937-952. https://doi.org/10.1177/0266666915575544

Merkel, C. B., Clitherow, M., Farooq, U., Xiao, L., Ganoe, C. H., Carroll, J. M., \& Rosson, M. B. (2005). Sustaining computer use and learning in community computing contexts: Making technology part of "Who They are and What They Do". The Journal of Community Informatics, 1(2), $158-174$.

O'Neil, D. (2002). Assessing community informatics: A review of methodological approaches for evaluating community networks and community technology centers. Internet Research: Electronic Networking Applications and Policy, 12(1), 76-102. https://doi.org/10.1108/10662240210415844

Osman, M. A., \& Tanner, M. (2017). The influence of telecentre components on the psychological empowerment of underserved community members in the Western Cape, South Africa. The Electronic Journal of Information Systems in Developing Countries, 81(1), 1-29. https://doi.org/10.1002/j.16814835.2017.tb00596.x

Oyedemi, T. D. (2009). Sociallnequalities and the South African ICT Access Policy Agendas. International Journal of Communication, 3, $151-168$.

Pade-Khene, C., \& Sewry, D. (2012). The rural ICT comprehensive evaluation framework: Implementing the first domain, the baseline study process. The Electronic Journal of Information Systems in Developing Countries, 51, 1-34. https://doi.org/10.1002/j.1681-4835.2012.tb00365.x

Pal, J., (2008), Computers and the promise of development: aspiration, neoliberalism and "technolity" in India's ICTDenterprise. Confronting the Challenge of Technology for Development: Experiences from the BRICS. Oxford: University of Oxford.

Parker, M., \& Wills, G. (2009). Improving the knowledge exchange landscape in the Cape Flats, a developing community in South Africa. SA Journal of Information Management, 11(3), 11 pages). https://doi.org/10.4102/sajim.v11i3.408

Parkinson, S., \& Lauzon, A. C. (2008). The impact of the Internet on local social equity: A study of a telecenter in Aguablanca, Colombia. Information Technologies and International Development, 4(3), 21-38. https://doi.org/10.1162/itid.2008.00015

Parkinson, S., \& Ramírez, R. (2007). Using a sustainable livelihoods approach to assessing the impact of ICTs in development. The Journal of Community Informatics, 2(3), http://ci-journal.net/index.php/ciej/article/view/310/263.

Parthasarathy, B., \& Srinivasan, J. (2006). Innovation and its social impacts: The role of ethnography in the evaluation and assessment of ICTD projects. Paper presented at the Global Network for Economics of Learning Innovation, and Competence Building Systems Conference, Tivandrum, India. http://www. globelicsindia2006.org/l-3/Balaji\%20Parthasarathy\%20336.doc

Pather, S. (2012, 7-9 November 2012). The role of public access ICT centres in local development: A study of the Cape Access programme. Paper presented at the 12th Annual Conference on World Wide Web Applications, Durban, South Africa.

Pather, S. \& Gomez, R. (2010). Public access ICT: A South-South comparative analysis of libraries, telecentres and cybercafés in South Africa and Brazil. AMCIS 2010 proceedings paper, 526.

Pather, S., \& Remenyi, D. (2005). Some of the philosophical issues underpinning research in information systems-From positivism to critical realism: Reviewed article. South African Computer Journal, 35, 76-83.

Pather, S., \& Uys, C. (2010, 5-8 January 2010). A strategy for evaluating socio-economic outcomes of an ICT4D programme. Paper presented at the Proceedings of the 43rd Annual Hawaii International Conference on System Sciences, Kauai, Hawaii.

Pigg, K. E., \& Crank, L. D. (2004). Building community social capital: The potential and promise of information and communications technologies. The Journal of Community Informatics, 1(1), 58-73.

Pitroda, S. (1993). Development, democracy, and the village telephone. Harvard Business Review, 71(6), 66-68.

Ray, I., \& Kuriyan, R. (2010). Towards aspiration as a development indicator: The case of information and communication technologies. Paper presented at the Proceedings of the 4th ACM/IEEE International Conference on Information and Communication Technologies and Development.

Rhodes, J. (2009). Using actor-network theory to trace an ICT (telecenter) implementation trajectory in an African women's micro-enterprise development organization. Information Technologies and International Development, 5(3), 1-20.

Rothenberg-Aalami, J., \& Pal, J. (2005). Rural telecenter impact assessments and the political economy of ICT for development BRIE Working Paper 164 (pp. 1-56). Berkley: Berkley Roundtable on the International Economy.

Rustøen, T. (1995). Hope and quality of life, two central issues for cancer patients: A theoretical analysis. Cancer Nursing, 18(5), 355-361.

Sen, A. (1990). Development as capability expansion. In K. Griffin (Ed.), Human development and the international development strategy for the 1990s. London: Macmillan.

Sen, A. (2001). Development as freedom. London: Oxford University Press. 
Sey, A., \& Fellows, M. (2011, 9-11 February). Loose strands: Searching for evidence of public access ICT impact on development. Paper presented at the Proceedings of the Global Impact Study, iConference, Seattle.

Smart Cape. (2010). SmartCape history. Retrieved from http://www.smartcape.org.za/about.html

South Africa. (2016). National Integrated ICT Policy White Paper. Department of Telecommunications and Postal Services (DTPS). Government Gazette, No. 40325 , Oct 3.

Statistics South Africa (2019). General Household Survey 2018. (statistical release P0318). Pretoria: StatsSA Retrieved from. http://www.statssa.gov.za/ publications/P0318/P03182018.pdf

Stillman, L., Herselman, M., Marais, M., Boshomane, M. P., Plantinga, P., \& Walton, S. (2011). Digital doorway: Social-technical innovation for high-needs communities. The Electronic Journal of Information Systems in Developing Countries, 50(2), 1-18.

Sturrock, K., \& Rocha, J. (2000). A multidimensional scaling stress evaluation table. Field Methods, 12(1), 49-60. https://doi.org/10.1177/ $1525822 \times 0001200104$

Tabassum, G., \& Yeo, A. W. (2015, May). Measurement of tangible and intangible impacts of telecentres on rural communities. In Proceedings of the Seventh International Conference on Information and Communication Technologies and Development (p. 61). ACM.

UNESCO. (2002). UNESCO action and the United Nations Millennium Development Goals. Bureau of Strategic Planning. Retrieved from http://www. unesco.org/bsp/eng/mdg.htm

United Nations. (2015). Post-2015 inter-governmental negotiations: Sustainable Develoment Goals and Targets. Sustainable Development Knowledge Platform. Retrieved from https://sustainabledevelopment.un.org/post2015/sdgsandtargets

Uys, C., \& Pather, S. (2016). Government public access centres (PACs): A beacon of hope for marginalised communities. The Journal of Community Informatics, 12(1), 21-52.

Van Rensburg, J., Veldsman, A., \& Jenkins, M. (2008). From technologists to social enterprise developers: Our journey as "ICT for Development" practitioners in Southern Africa. Information Technology for Development, 14(1), 76-89. https://doi.org/10.1002/itdj.20088

Walton, M., \& Donner, J. (2012). Public access, private mobile: The interplay of shared access and the mobile Internet for teenagers in Cape Town. Global Impact Study Research Report Series. Cape Town, South Africa: University of Cape Town.

Ward, J., \& Daniel, E. (2006). Benefits management: Delivering value from IS and IT investments (1st ed.). West Sussex. UK: Wiley.

Western Cape Government. (n.d.). Cape Access. Retrieved from https://www.westerncape.gov.za/capeaccess/about-cape-access

Williams, J., Sligo, F., \& Wallace, C. (2005). Free Internet as an agent of community transformation. The Journal of Community Informatics, 2(1), 53-67.

Yin, R. K. (2009). Case study research design and methods (4th ed., Vol. 5). Thousand Oaks, CA: Sage.

\section{AUTHOR BIOGRAPHIES}

Corrie Uys (previously Strümpfer) joined higher education in 1992 as a lecturer in statistics and computer programming at the then Cape Technikon. She completed an MSc in Statistics at UNISA in 2002 and A DTech Informatics in 2015. Her thesis title was "Framework for Evaluating Information Technology Benefits in Local Communities." Dr Uys is a statistician with 20 years of experience in applied statistics consultation with various entities and postgraduate research. Currently, she provides research mentorship to postgraduate students and staff involved in research in quantitative (and qualitative-to a lesser degree) paradigms. Her research focuses on (a) research support/consultation including statistical support to all CPUT staff and students involved in research projects and postgraduate studies in all faculties since 2007 and (b) evaluating ICT4D projects deployed in communities. Her research interests include ICT4D, community informatics, and research methodology and statistics.

Shaun Pather is a professor of information systems in the Faculty of Economic and Management Sciences at the University of the Western Cape. He is a Fulbright Scholar and has over 27 years of work experience in the broad education and ICT sectors. He holds a Doctor of Technology degree in information technology and is actively involved from both research and policy perspectives with government, industry, and non-profit organisations. Shaun's current research focuses on advancing the Information Society in developing countries. He is passionate about the use of ICTs for societal upliftment and the nexus thereof on public policy.

How to cite this article: Uys C, Pather S. A benefits framework for public access ICT4D programmes. E J Info Sys Dev Countries. 2020;86: e12119. https://doi.org/10.1002/isd2.12119 


\section{APPENDIX A: 6.1 | Code and theme structure}

\begin{tabular}{|c|c|c|c|}
\hline Agency & Changed Life & Choice & Community Involvement \\
\hline Empowerment-create and email CV & $\begin{array}{l}\text { Benefit of ICT centre-change lives for the } \\
\text { better }\end{array}$ & $\begin{array}{l}\text { Choice } \\
\text { existence }\end{array}$ & Advocacy \\
\hline $\begin{array}{l}\text { Empowerment through being able to learn } \\
\text { independently }\end{array}$ & & & Collective efficacy \\
\hline Empowerment through learning new skills & & & $\begin{array}{l}\text { Local community } \\
\text { development }\end{array}$ \\
\hline \multicolumn{4}{|l|}{ Self-efficacy } \\
\hline Self-esteem & & & \\
\hline
\end{tabular}

Abbreviations: CV, curriculum vitae; ICT, information and communications technology.

\begin{tabular}{|c|c|c|}
\hline ICT Usage & Learning Opportunities & Opportunities \\
\hline Benefit of ICT centre-access to computers & Benefit of ICT centre-assist in studies & $\begin{array}{l}\text { Biography-frequency of visiting ICT } \\
\text { Centre }\end{array}$ \\
\hline Benefit of ICT centre-search for employment & Benefit of ICT centre-gives knowledge & Biography-structure of a day \\
\hline Benefit of ICT centre-use email & Benefit of Library-increases reading skills & \\
\hline Benefit of ICT centre-use Internet for research & $\begin{array}{l}\text { Benefit of library-reading increases English } \\
\text { language skills }\end{array}$ & \\
\hline Benefit of ICT centre-use social networks & Biography-education & \\
\hline Content creation & Social capacity building & \\
\hline \multicolumn{3}{|l|}{ Innovation } \\
\hline \multicolumn{3}{|l|}{$\begin{array}{l}\text { Usage pattern: use word processor, spreadsheets and } \\
\text { Internet }\end{array}$} \\
\hline Usefulness of ICT centre-use as "work office" & & \\
\hline
\end{tabular}

Abbreviation: ICT, information and communications technology.

\section{Social Capital \\ Benefit of ICT centre-connect with lost friends \\ Benefit of ICT centre-use social networks \\ Benefit of library-meet new people \\ Biography-access to Internet from cellphone}

Abbreviation: ICT, information and communications technology. 